\title{
Photonic Crystal-Based Biosensor for Detection of Human Red Blood Cells Parasitized by Plasmodium Falciparum
}

\author{
Ali Rashidnia \\ Shiraz University of Technology \\ H Pakarzadeh ( $\square$ pakarzadeh@sutech.ac.ir) \\ Shiraz University of Technology \\ Mohsen Hatami \\ Shiraz University of Technology \\ Natesan Ayyanar \\ National Institute of Technology Tiruchirappalli
}

\section{Research Article}

Keywords: Plasmodium falciparum, photonic crystal, ring resonator, biosensor, visible wavelength, FDTD, PWE

Posted Date: July 12th, 2021

DOI: https://doi.org/10.21203/rs.3.rs-655711/v1

License: (c) (i) This work is licensed under a Creative Commons Attribution 4.0 International License. Read Full License

Version of Record: A version of this preprint was published at Optical and Quantum Electronics on December 7th, 2021. See the published version at https://doi.org/10.1007/s11082-021-03421-w. 


\title{
Photonic Crystal-Based Biosensor for Detection of Human Red Blood Cells Parasitized by Plasmodium Falciparum
}

\author{
Ali Rashidnia ${ }^{a}$, Hassan Pakarzadeh ${ }^{a^{*}}$, Mohsen Hatami ${ }^{a}$, and Natesan Ayyanar \\ aDepartment of Physics, Shiraz University of Technology, Shiraz, Iran \\ ${ }^{b}$ Department of ECE,National Institute of Technology, Thiruchirapalli-620015,Tamilnadu,India \\ Corresponding author's e-mail: Pakarzadeh@sutech.ac.ir
}

\begin{abstract}
In this paper, a biosensors based on a two-dimensional photonic crystal (2D PhC) waveguide including a ring resonator is designed and simulated based on refractive index changes of red blood cells. The proposed biosensor structure consists of an elliptical photonic crystal ring resonator and two linear waveguides containing silicon nitride rods in a 2D rectangular lattice with circular rods. The biosensor is utilized to detect the stages of the Plasmodium falciparum cycle in red blood cells and to diagnose malaria disease. The proposed design distinguishes with high sensitivity between normal red blood cells and cells infected with Plasmodium falciparum. This biosensor is very compact, consists of gold rods in the air background and works very well at two input central wavelengths of $0.514 \mu \mathrm{m}$ and $1.55 \mu \mathrm{m}$. The finite-difference time-domain (FDTD) method is used to simulate and investigate the device. The biosensor is extremely compact which is very suitable for lab-on-chip applications and exhibits higher sensitivity at both input central wavelengths compared with that of previously reported sensors.
\end{abstract}

Keywords: Plasmodium falciparum; photonic crystal; ring resonator; biosensor; visible wavelength; FDTD; PWE. 


\section{Introduction}

Malaria is a dangerous human disease that is one of the leading causes of morbidity and mortality in children as well as adults in endemic countries. About $44 \%$ of the world's population is at risk for the disease (Nureye and Assefa 2020). Its rapid and efficient diagnosis is essential to prevent complications and mortality, as well as to treat and manage the disease (Bilal et al. 2015). The five types of Plasmodium that cause the disease are P.falciparum, P.vivax, P. ovale, P. malariae, and P. knowlesi, of which most malaria deaths are associated with P. falciparum infections. The parasite is generally transmitted to humans by the bite of an infected Anopheles mosquito (Molina-Franky et al. 2020). At this time, the life cycle of Plasmodium begins and the parasites enter the bloodstream in the form of sporozoites and attack the liver cells. When the hepatocytes are destroyed, the parasites enter the bloodstream as merozoites and attack the red blood cells and finally begin an intraerythrocytic cycle. This cycle causes structural and biochemical changes in red blood cells. The beginning of this cycle is the ring phase, which is caused by merozoites attacking red blood cells, followed by mononuclear trophozoites. Later, trophozoites transform into multinucleated cells called schizonts, which are formed by the breakdown of hemoglobin and the production of hemozoin (Liu et al. 2016). In the intraerythrocytic cycle, infected erythrocytes show a heterogeneous distribution of refractive index throughout the cytoplasm of the cell, while healthy erythrocytes have a homogeneous refractive index distribution (Akpa Marcel et al. 2019). This significant refractive index difference between healthy and infected red blood cells can be used as an essential parameter for the diagnosis of malaria (Bendib and Bendib 2018).

The main method for confirming malaria infection is based on a blood smear examination with a light microscope, which requires an experienced and trained laboratory specialist, and the speed of achieving results is relatively slow (Ragavan et al. 2018). The other two methods used to diagnose malaria include rapid diagnostic testing (RDT) and polymerase chain reaction (PCR). In the former, there are many concerns about their sensitivity and specificity that limit their impact, and the latter are expensive and time consuming and require trained personnel (Krampa et al. 2020). The use of RDT and light microscopy to diagnose malaria in febrile patients is sufficient, however, a more efficient and faster tool is 
needed to diagnose malaria (Bilal et al. 2015). Sensitivity and specificity of optical techniques to produce high-precision data are essential for improving the tools available in future research on blood diseases (Bendib and Bendib 2018).

Photonic crystal $(\mathrm{PhC})$-based biosensor is one of these optical techniques that has been considered due to its properties such as light confinement and compression (Sharma and Sharan 2015). The sensing mechanism in photonic crystals is based on the propagating mode effective index change. The propagating mode effective index change is produced by two methods, the first by changing the refractive index of the $\mathrm{PhC}$ cover medium or homogeneous sensing and the other method by changing the thickness of an ultra-thin layer of immobilized receptor molecules on the PhC surface or surface sensing (Dell'Olio and Passaro 2007). With changes in refractive index, the resonance wavelength of the $\mathrm{PhC}$ has changed, which leads to high sensitivity, which is the basis for detecting label free $\mathrm{PhC}$ biosensors (Divya et al. 2018).

Photonic crystals are highly compact and suitable for use in lab on a chip. They are easy to design and can detect small changes in the refractive index with a small sample size (Zhang et al. 2017). Photonic crystal ring resonator (PCRR) has the advantages of very high sensitivity, small size, high quality factor and very good light confinement (Sharma and Sharan 2015). PCRR-based sensors are used to measure temperature (Zegadi et al. 2019; Rajasekar and Robinson 2018), pressure (Rajasekar and Robinson 2018; Krishnan and Robinson 2014), force and strain (Mai et al. 2011), biomolecules such as DNA (Hsiao and Lee 2010). Also, determining various components of blood (Sharma and Sharan 2015; Rajendran et al. 2018) and determining the concentration of glucose in urine (Robinson and Dhanlaksmi 2016) are other applications.

In this paper, we design and simulate a two-dimensional (2D) $\mathrm{PhC}$ biosensor with a rectangular arrangement of gold rods distributed in the air background with both input central wavelengths of $0.514 \mu \mathrm{m}$ and $1.55 \mu \mathrm{m}$. The design priority of the biosensor at the input central wavelength is $0.514 \mu \mathrm{m}$ because at wavelengths of less than one micrometer, water absorption is negligible and causes less damage to biological cells, which is the advantages of the proposed biosensor that is excited by visible light. Also, abundant access to high-performance detectors, low-cost 
light sources and high performance are other advantages (Subramanian et al. 2015).

\section{Proposed 2D PhC-Based Biosensor Design}

As it is shown in Fig.1, the 2D PhC-based biosensor is created with a ring resonator from a rectangular arrangement of gold rods (yellow area) in the air background (white area). The ring resonator in the middle of the structure can be made of rods with different geometry as will be described later on. The gold permittivity can be defined via the Drude model as (Chen et al. 2019; Hassani and Skorobogatiy 2009; Hameed et al. 2015):

$$
\varepsilon(\omega)=\varepsilon_{\infty}-\frac{\omega_{p}^{2}}{\omega\left(\omega+i \omega_{c}\right)}
$$

where $\varepsilon_{\infty}$ is the dielectric permittivity of gold at high frequency and its value is $9.75, \omega_{\mathrm{p}}=1.36 \times 10^{16} \mathrm{rad} / \mathrm{s}$ is the plasma frequency and the value of $\omega_{\mathrm{c}}$ is $1.45 \times 10^{14}$ $\mathrm{rad} / \mathrm{s}$. The air refractive index is 1 and the radius of the rods and the lattice constant are $0.2 \mu \mathrm{m}$ and $0.45 \mu \mathrm{m}$, respectively. The number of rods in the $\mathrm{x}$ and $\mathrm{z}$ directions is 13 and 21, respectively. The size of this biosensor is $9.82 \times 6 \mu \mathrm{m}^{2}$.

It should be noted that the ring resonator shown in Fig. 1 was created by removing and changing the radius of the gold rods. The input and output waveguides is generated by removing six gold rods. Inside the waveguides were placed silicon nitride $\left(\mathrm{Si}_{3} \mathrm{~N}_{4}\right)$ rods, shown in orange in Figure 1.

The refractive index of silicon nitride was obtained according to the following Sellmeier equation (Bååk 1982):

$$
n^{2}(\lambda)=1+\frac{2.8939 \lambda^{2}}{\lambda^{2}-(0.13967)^{2}}
$$




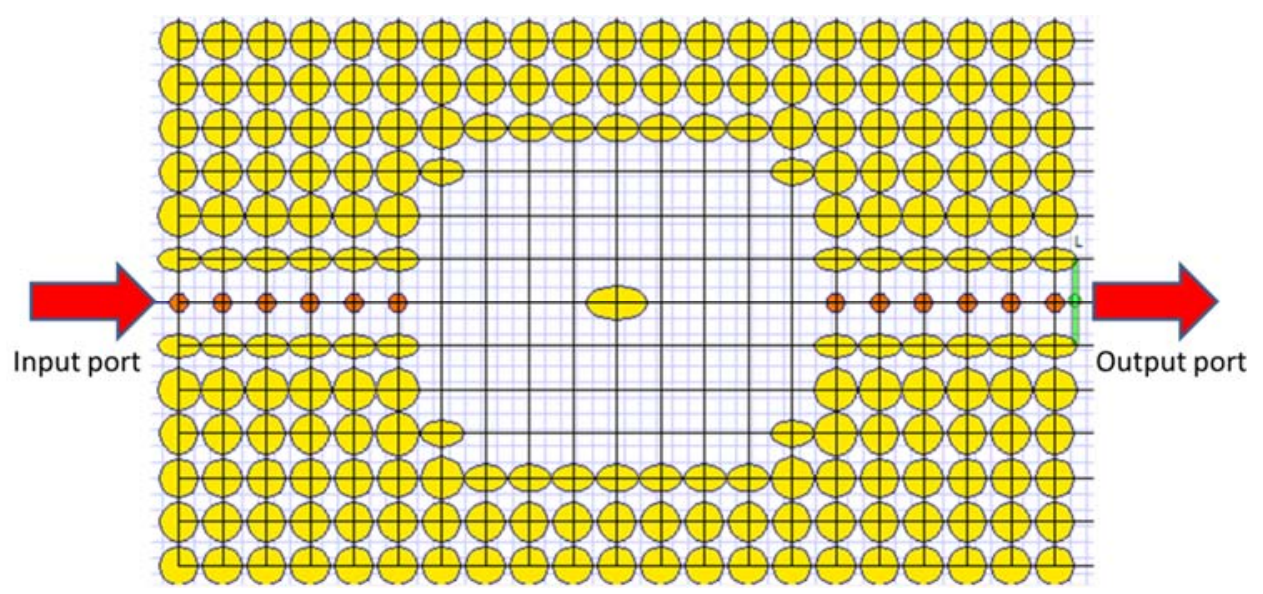

Fig. 1. The proposed 2D PhC-based biosensor. The yellow area corresponds to gold rods and the white region is related to the air background. Silicon nitride $\left(\mathrm{Si}_{3} \mathrm{~N}_{4}\right)$ rods, shown in orange.

The chemical, mechanical, and thermal stability of silicon nitride, as well as its range of transparency, from visible to mid-infrared, are important features for biochemical and medical measurement applications. High-accuracy sensors based on light guiding mechanisms have been reported in photonic integrated circuits (PICs) made of silicon nitride. Silicon nitride has two important physical properties: very low propagation loss and nonlinear response. The latter is used to generate specific selective wavelengths. Many wavelengths can be combined together due to very low propagation loss in very complex circuits (Porcel et al. 2019). The proposed biosensor structure was optimized by changing the radius of the gold rods adjacent to the ring resonator and the output and input waveguides, as well as the silicon nitride rods. The goal of optimization is to achieve high sensitivity, high quality factor and high normalized output power simultaneously. Two important parameters for evaluating any biosensor are quality factor and sensitivity. Quality factor is the ratio of resonant wavelength ( $\left.\lambda_{\text {resonant }}\right)$ to full width at half maximum (FWHM) of the output of the waveguide, expressed as:

$\mathrm{Q}=\frac{\lambda(\text { resonant })}{\mathrm{FWHM}}$

Sensitivity of the ratio of resonance wavelength changes to changes the refractive index is expressed as (Mohammed et al. 2019):

$\mathrm{S}=\frac{\Delta \lambda}{\Delta \mathrm{n}}$ 
Normalized output power indicates the amount of power loss. The higher the normalized output power, the lower the power loss (Sharma and Sharan 2015). Elliptical gold rods with a larger radius of $R_{A}(\mu \mathrm{m})$ and a smaller radius of $r_{A}(\mu \mathrm{m})$, and circular gold rods with a radius of $R_{B}(\mu \mathrm{m})$, form the ring resonator, shown in Figure 2 with the letters $A$ and $B$, respectively. Elliptical gold rods, including input and output waveguides with a larger radius of $R_{C}(\mu \mathrm{m})$ and a smaller radius of $r_{C}$ $(\mu \mathrm{m})$, shown in Figure 2 with the letters C. Also, in the middle of the ring resonator, which is shown with the letter $\mathrm{D}$, an elliptical gold rod with a larger radius of $R_{D}$ $(\mu \mathrm{m})$ and a smaller radius of $\mathrm{r}_{\mathrm{D}}(\mu \mathrm{m})$ has been used.

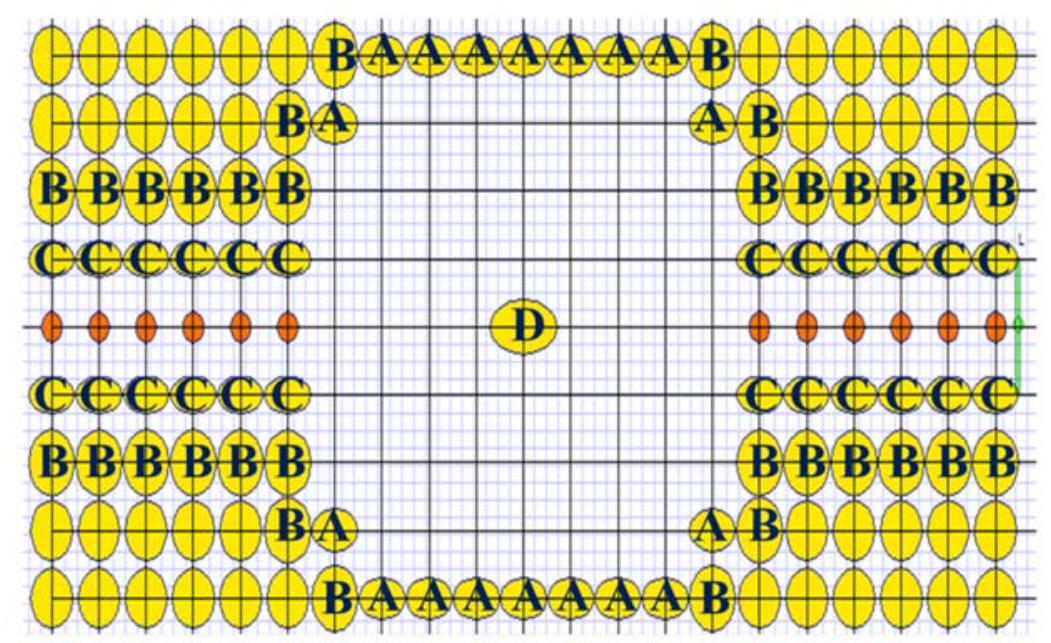

Fig. 2. Dimensions of the rods that make up the ring resonator and waveguides. A is elliptical gold rods with a larger radius of $R_{A}(\mu \mathrm{m})$ and a smaller radius of $r_{A}(\mu \mathrm{m})$ and $B$ is gold rods with a radius of $R_{B}(\mu m)$. $C$ is elliptical gold rods with a larger radius of $R_{C}(\mu \mathrm{m})$ and a smaller radius of $r_{C}(\mu \mathrm{m})$. $D$ is an elliptical gold rod with a larger radius of $R_{D}(\mu m)$ and a smaller radius of $r_{D}(\mu m)$.

Phosphate-buffered saline (PBS) is used as a reference material with a refractive index of 1.336 (Barroso et al. 2019). When this biosensor is immersed in a sample containing buffer, air gives way to buffer. To use erythrocytes as analytes, they must be isolated from whole blood and diluted in PBS buffer, which is done by the process of sequentially centrifuging the blood and discarding the serum and plasma and adding buffer as reported in the articles (Chopra et al. 2016; Dharmadhikari et al. 2013). To identify normal and infected red blood cells, their solution replaces the PBS buffer, which changes the refractive index and changes the light propagation in the photonic crystal. The refractive indices of normal red blood cells and infected red blood cells diluted in PBS buffer are 1.399, 1.395, 1.383, and 
1.373 in the ring stage, trophozoite stage, and schizont stage, respectively )Park et al. 2008). The proposed scheme is simulated by OptiFDTD software using FDTD method, which is a numerical method for solving Maxwell equations for photonic crystal structures (Mohammed et al. 2019). As well as, the band gap of 2D PhC structure without defect is calculated through the FDTD method with the Lumerical software.

\section{Results and Discussion}

The FDTD method is used to simulate photonic band gaps (PBGs) of 2D PhC structure without defect. FDTD calculations are confirmed by comparing the results with the PWE method for rectangular lattice of silicon $(n=3.46)$ rods without defect in PBS buffer with the same lattice constant and rod radius. Plane wave expansion (PWE) method was performed with optiFDTD software. In Figures 3 and 4, The Solid red lines and the black dots show the bands calculated using PWE and FDTD methods for TM and TE modes, respectively.

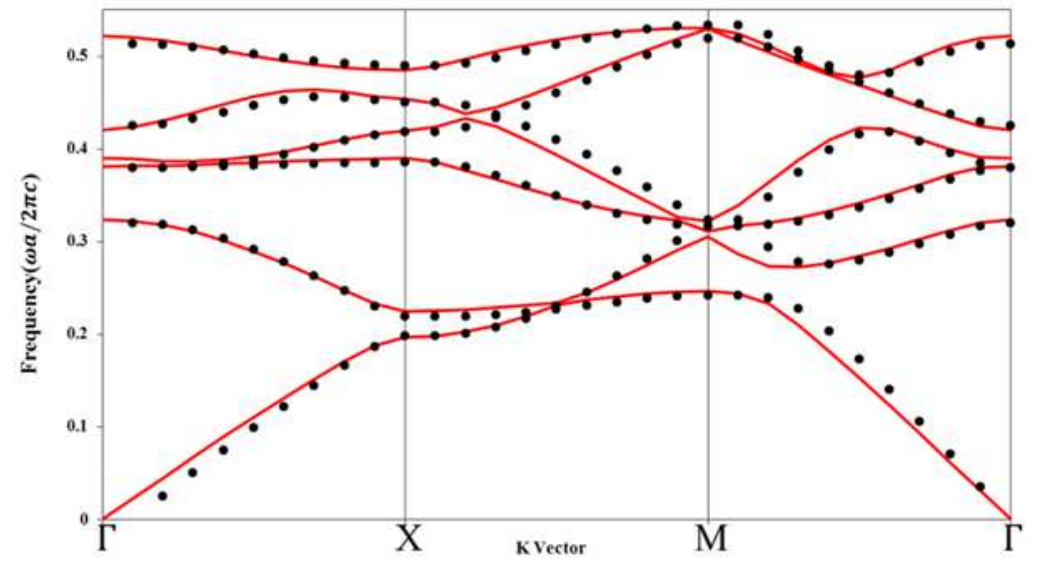

Fig. 3. Band structure of $2 \mathrm{D}$ photonic crystal in rectangular lattice of silicon rods without defect for transverse magnetic mode (TM) in PBS buffer. 


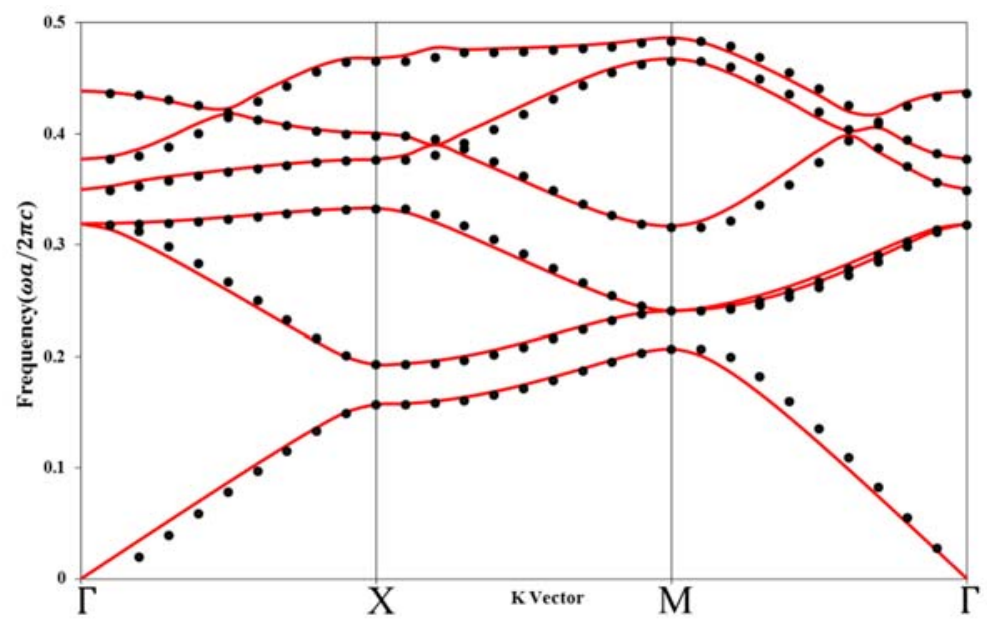

Fig. 4. Band structure of 2D photonic crystal in rectangular lattice of silicon rods without defect for transverse electric mode (TE) in PBS buffer.

As can be seen from Figure 3 and 4, there is no photonic band gap for TM and TE modes. This study confirms our FDTD approach because the FDTD results are well consistent with the results produced by the PWE method. As shown in Fig.5 in gray, the proposed 2D metallic photonic crystal (MPhc) structure without defect has two PBGs in the buffer for transverse electric mode (TE). In metallic photonic crystals, there is a cut-off frequency (Degirmenci and Landais 2013), and the frequency range between the zero and cut-off frequencies forms the first band. Therefore, the first band is between 0 and $0.762665 \mathrm{a} / \lambda$. The second band gap is between 0.77047 and $0.977396 \mathrm{a} / \lambda$, which is related to the wavelength range of 460.407 to $584.059 \mathrm{~nm}$. The second PBG was used to design the biosensor at the input central wavelength of $0.514 \mu \mathrm{m}$. 


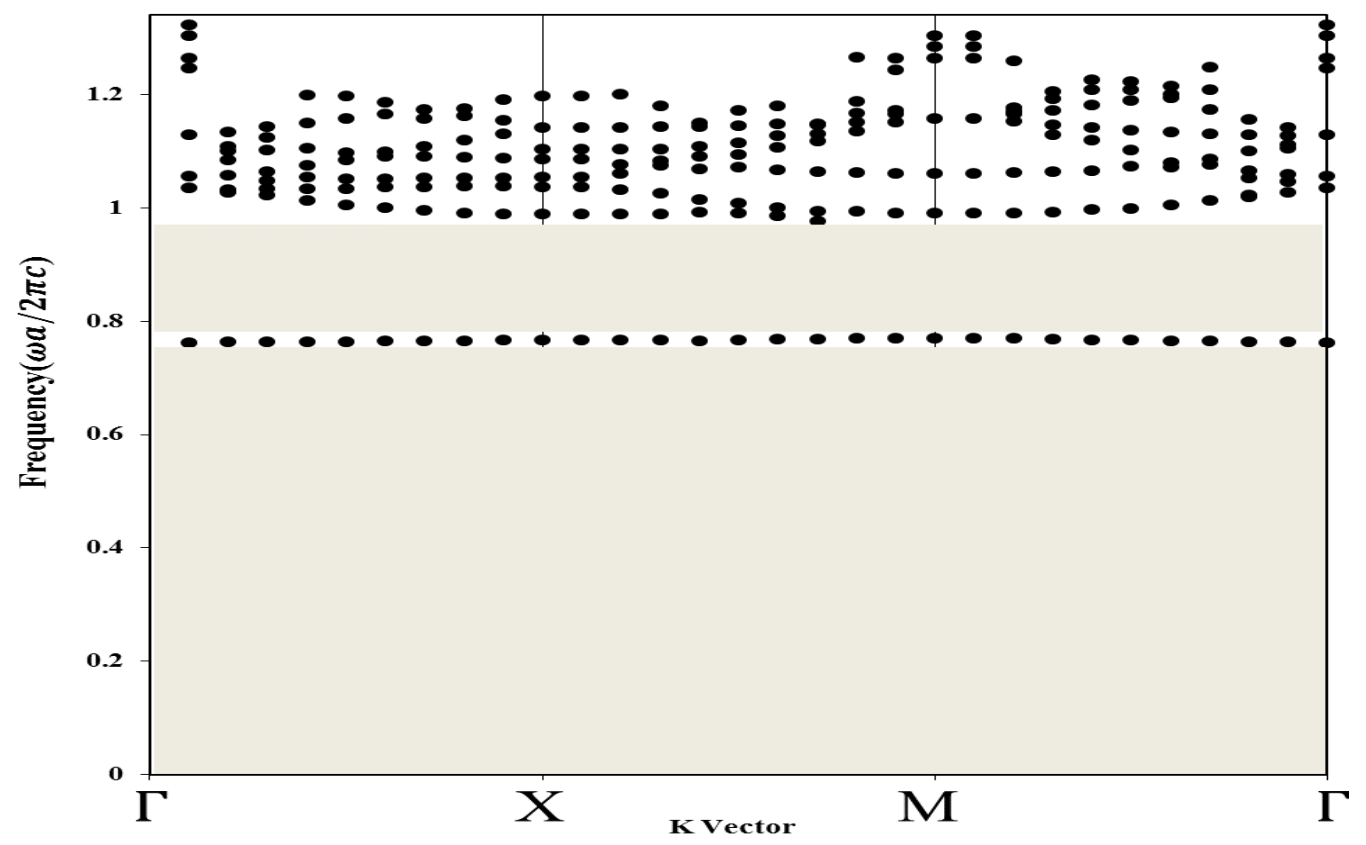

Fig. 5. Photonic band gaps of the 2D MPhc structure without defect for transverse electric mode (TE) in PBS buffer.

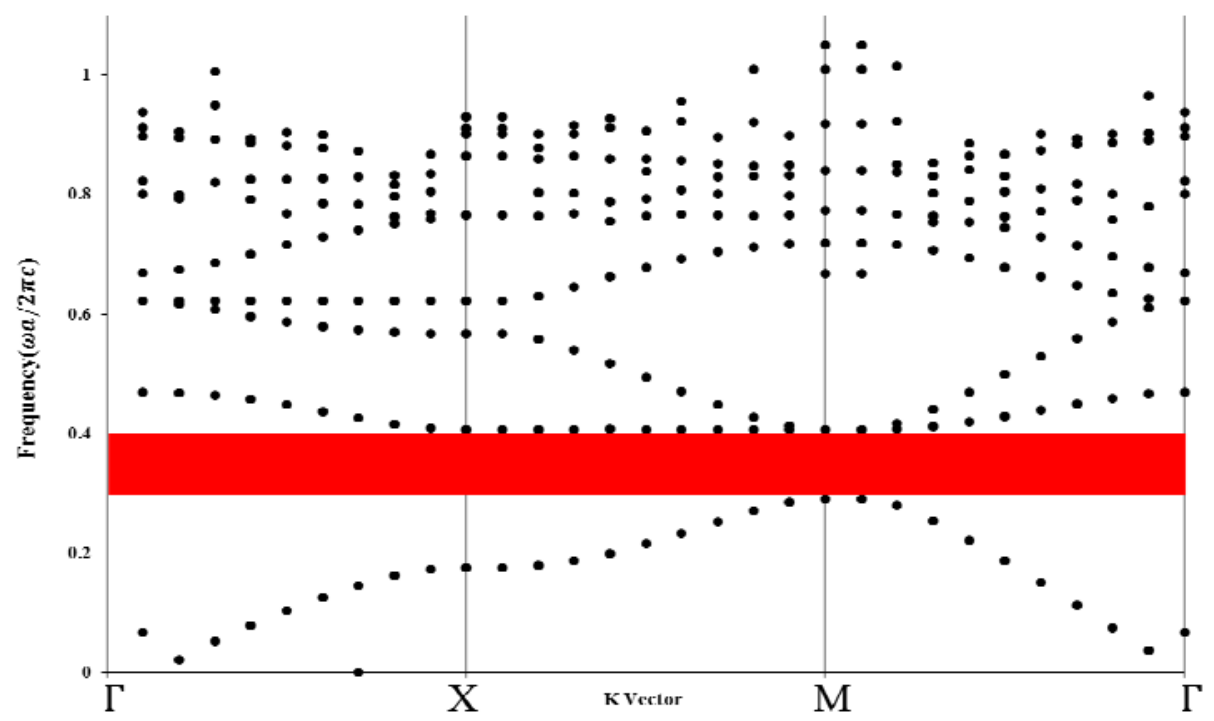

Fig. 6. Photonic band gaps of the 2D MPhc structure without defect for transverse magnetic mode (TM) in PBS buffer.

Also, as shown in Figure 6, this structure has a PBG in the buffer for transverse magnetic (TM) mode. This PBG is between 0.290555 and $0.406783 \mathrm{a} / \lambda$, which is in the wavelength range of 1106.241 to $1548.760131 \mathrm{~nm}$ and is not considered. In Fig.7, the photonic band gaps of the $2 \mathrm{D} \mathrm{PhC} \mathrm{structure} \mathrm{without} \mathrm{defect} \mathrm{it} \mathrm{was} \mathrm{shown} \mathrm{for} \mathrm{transverse}$ 
electric mode (TE) and refractive indices, normal red blood cell and malaria-infected blood cells.

(a)

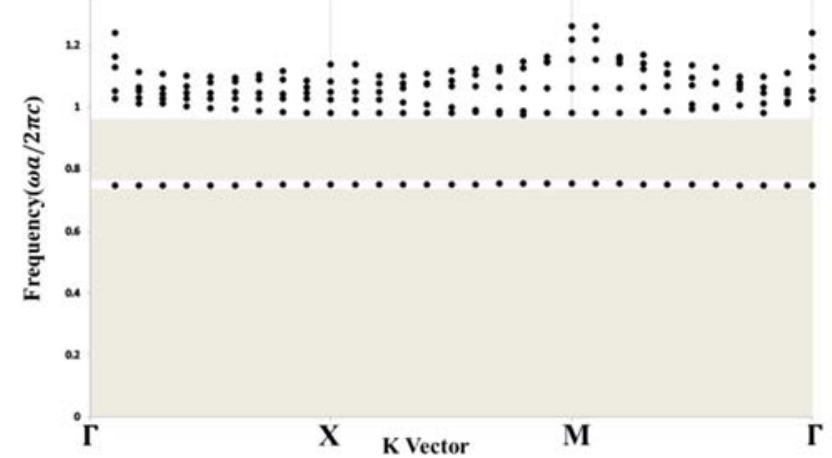

(c)

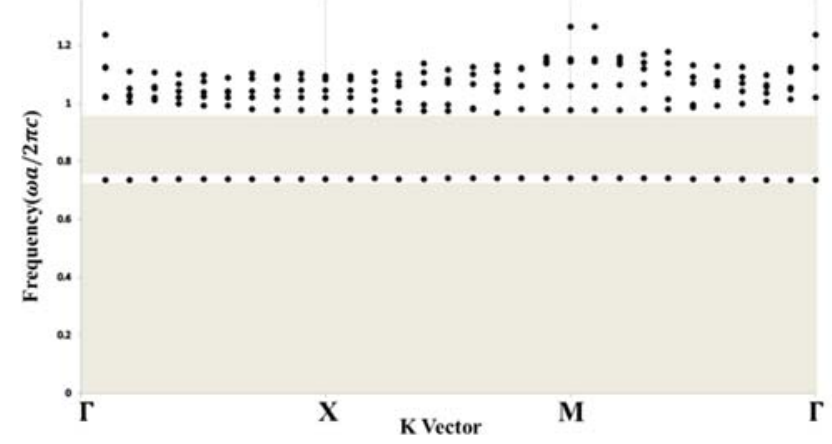

(b)

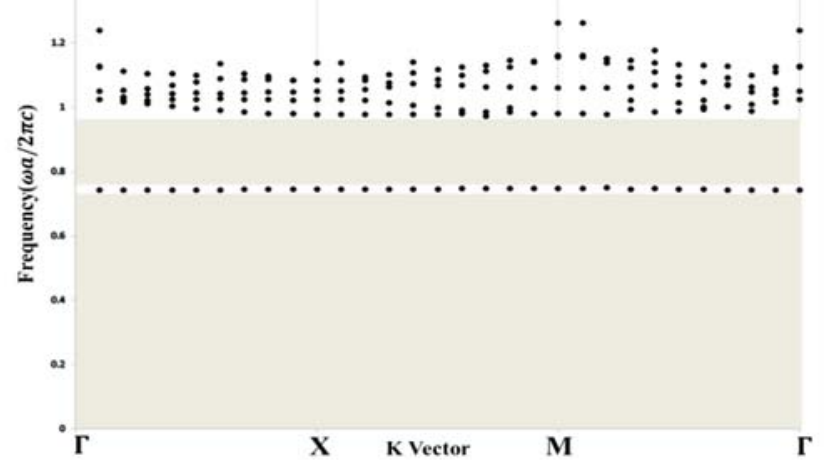

(d)

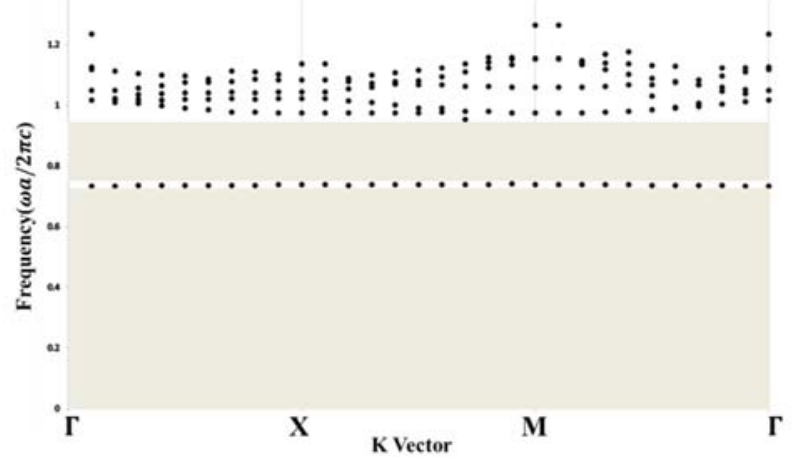

Fig. 7. Photonic band gaps of the 2D MPhc structure without defect for transverse electric mode (TE) in (a) schizont stage (b) trophozoite stage (c) ring stage (d) normal red blood cell.

Table1 shows, the PBG wavelength range shifts to larger values as the background refractive index increases. However, in the second band gap $0.514 \mu \mathrm{m}$ wavelength is still in the PBG wavelength range for this range of refractive indices. 
Table 1. The values of PBG width, normalized frequencies, and wavelength range for the first band gap and second band gap, respectively, for the refractive index, PBS, normal red blood cells, and malaria-infected red blood cells.

\begin{tabular}{|c|c|c|c|c|}
\hline Refractive Index & $\begin{array}{c}\text { PBG width } \\
\text { (first band gap) }\end{array}$ & $\begin{array}{c}\text { Normalized frequencies(a/ } \boldsymbol{\lambda} \text { ) } \\
\text { (first band gap) }\end{array}$ & $\begin{array}{c}\text { PBG width } \\
\text { (second band gap) }\end{array}$ & $\begin{array}{c}\text { Wavelength range (nm) } \\
\text { ( second band gap) }\end{array}$ \\
\hline $\begin{array}{c}\text { Normal red blood cell } \\
1.399\end{array}$ & 0.734832 & 0.734832 & 0.21224 & $472.1995-607.4949$ \\
\hline $\begin{array}{c}\text { Ring stage } \\
1.395\end{array}$ & 0.73676 & 0.73676 & 0.22591 & $464.741-606.166$ \\
\hline $\begin{array}{c}\text { Trophozoite stage } \\
1.383\end{array}$ & 0.742016 & 0.742016 & 0.223454 & $462.3926-600.2041$ \\
\hline $\begin{array}{c}\text { Schizont stage } \\
1.373\end{array}$ & 0.746473 & 0.746473 & 0.222436 & $461.253-597.476$ \\
\hline $\begin{array}{c}\text { PBS buffer } \\
1.336\end{array}$ & 0.762665 & 0.762665 & 0.206926 & $460.407-584.059$ \\
\hline
\end{tabular}

The Proposed 2D PhC-Based Biosensor is also excited by a Gaussian modulated continuous wave from a light source with a central wavelength of $0.514 \mu \mathrm{m}$ using the Anisotropic Perfectly Matched Layers (APML) boundary conditions.

The spatial step sizes $\Delta x$ and $\Delta z$ of the grid in FDTD simulation were considered to be $10 \mathrm{~nm}$. The time step size $\Delta t$, for the stability of the simulation, must satisfy the following relation:

$$
\Delta \mathrm{t} \leq \frac{1}{c \sqrt{\left(\frac{1}{\Delta \mathrm{x}}\right)^{2}+\left(\frac{1}{\Delta \mathrm{z}}\right)^{2}}}
$$

where $\mathrm{c}$ is the speed of light in free space (Zegadi et al. 2019). Simulations were also performed during 100,000 time steps. The optimization of the radii of gold rods and silicon nitride rods, which are $R_{A, C}, r_{A}, R_{B}, r_{C}, R_{D}, r_{D}$ and $R_{S i 3 N 4}$ for normal red blood cells ( $\mathrm{n}=1.399)$, is shown in Table 2 . 
Table 2. The optimization of the radii of gold rods and silicon nitride rods

\begin{tabular}{|c|c|c|c|c|c|c|c|c|c|}
\hline $\begin{array}{l}\mathbf{R}_{\mathrm{Si3N} 4} \\
(\mu \mathrm{m})\end{array}$ & $\begin{array}{l}\mathbf{R}_{\mathrm{A}, \mathrm{C}} \\
(\mu \mathrm{m})\end{array}$ & $\begin{array}{c}\mathbf{r}_{\mathrm{A}} \\
(\mu \mathrm{m})\end{array}$ & $\begin{array}{c}\mathbf{R}_{\mathrm{B}} \\
(\mu \mathrm{m})\end{array}$ & $\begin{array}{c}\mathbf{r}_{\mathrm{C}} \\
(\mu \mathrm{m})\end{array}$ & $\begin{array}{c}\mathbf{R}_{\mathrm{D}} \\
(\mu \mathrm{m})\end{array}$ & $\begin{array}{c}\mathbf{r}_{\mathrm{D}} \\
(\mu \mathrm{m})\end{array}$ & $\begin{array}{r}\text { Sensitivity } \\
\text { (nm/RIU) }\end{array}$ & $\begin{array}{l}\text { Quality } \\
\text { factor }\end{array}$ & $\begin{array}{c}\text { Normalized output } \\
\text { power } \\
\text { Transmission }\end{array}$ \\
\hline 0.08 & 0.22 & 0.14 & 0.22 & 0.12 & 0.3 & 0.18 & 348.634 & 62.293 & 0.310450357 \\
\hline 0.1 & 0.22 & 0.14 & 0.22 & 0.12 & 0.3 & 0.18 & 357.217 & 142.242 & 0.311075109 \\
\hline 0.12 & 0.22 & 0.14 & 0.22 & 0.12 & 0.3 & 0.18 & 355.782 & 182.590 & 0.201255324 \\
\hline 0.1 & 0.18 & 0.14 & 0.22 & 0.12 & 0.3 & 0.18 & 352.568 & 143.570 & 0.180112587 \\
\hline 0.1 & 0.22 & 0.12 & 0.22 & 0.12 & 0.3 & 0.18 & 361.556 & 119.494 & 0.270049568 \\
\hline 0.1 & 0.22 & 0.14 & 0.22 & 0.14 & 0.3 & 0.18 & 354.613 & 137.212 & 0.248784327 \\
\hline 0.1 & 0.22 & 0.14 & 0.22 & 0.12 & 0.28 & 0.18 & 357.366 & 147.785 & 0.299314109 \\
\hline 0.1 & 0.22 & 0.14 & 0.22 & 0.12 & 0.32 & 0.18 & 356.985 & 127.085 & 0.31457014 \\
\hline 0.1 & 0.22 & 0.14 & 0.22 & 0.12 & 0.3 & 0.16 & 359.184 & 132.782 & 0.318388413 \\
\hline 0.1 & 0.22 & 0.14 & 0.22 & 0.12 & 0.3 & 0.2 & 355.492 & 137.139 & 0.292653987 \\
\hline 0.1 & 0.2 & 0.14 & 0.22 & 0.12 & 0.3 & 0.18 & \multirow{5}{*}{\multicolumn{3}{|c|}{ See Figure 8 and text. }} \\
\hline 0.1 & 0.22 & 0.16 & 0.22 & 0.12 & 0.3 & 0.18 & & & \\
\hline 0.1 & 0.22 & 0.14 & 0.2 & 0.12 & 0.3 & 0.18 & & & \\
\hline 0.1 & 0.22 & 0.14 & 0.18 & 0.12 & 0.3 & 0.18 & & & \\
\hline 0.1 & 0.22 & 0.14 & 0.22 & 0.1 & 0.3 & 0.18 & & & \\
\hline
\end{tabular}

$\mathbf{R}_{A, C}{ }^{*}$ : The values of $R_{A}$ and $R_{C}$ are the same.

As can be seen in Figure 8(a), the reason for choosing the $0.22 \mu \mathrm{m}$ size for $R_{B}$ is that at 0.2 and $0.18 \mu \mathrm{m}$ the Normalized output power Transmission is low and resonant wavelengths are close to each other and overlap. The output spectrum is also widened at $0.18 \mu \mathrm{m}$. This problem also exists for $\mathrm{R}_{\mathrm{A}, \mathrm{C}}=0.2, \mathrm{r}_{\mathrm{A}}=0.16, \mathrm{r}_{\mathrm{C}}=0.1$, and the shape of the output spectrum has become unusual. The value of Normalized output power Transmission for the radii of $\mathrm{R}_{\mathrm{A}, \mathrm{C}}, \mathrm{r}_{\mathrm{A}}$ and $\mathrm{r}_{\mathrm{C}}$ in Figures $8(\mathrm{~b}), 8(\mathrm{c})$ and $8(\mathrm{~d})$ are compared with the values of $0.22 \mu \mathrm{m}, 0.14 \mu \mathrm{m}$ and $0.12 \mu \mathrm{m}$, respectively. 

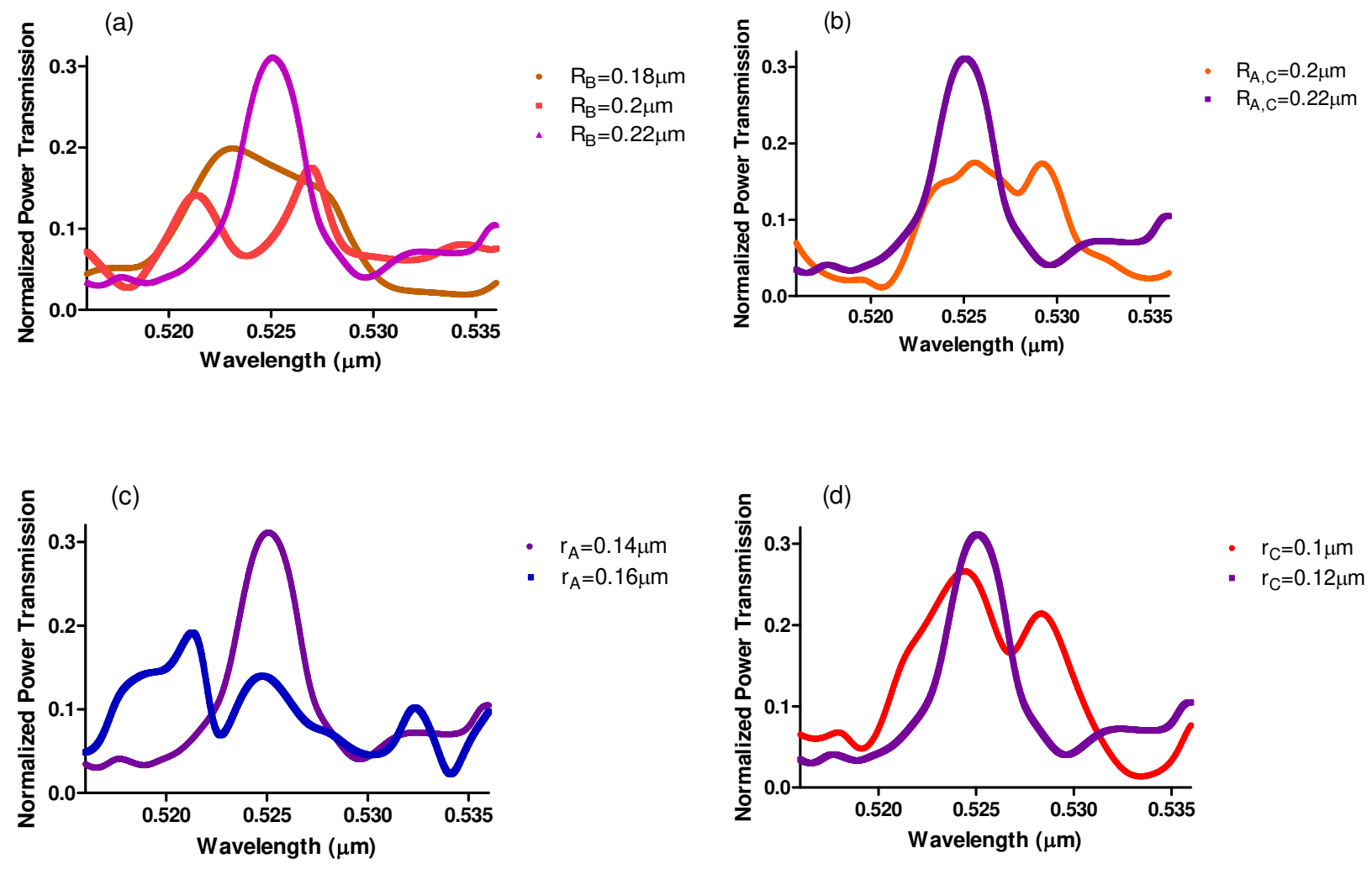

Fig. 8. Normalized output power transmission spectrum for (a) $R_{B}(b) R_{A, C}(c) r_{A}(d) r_{C}$.

As can be seen in Table 2, the values highlighted in green have a good balance between sensitivity, quality factor and normalized output power simultaneously.

The electric field distribution of elliptical ring resonator of designed biosensor at the resonant wavelength $0.52508 \mu \mathrm{m}$ is shown in Fig. 9. Transmission spectra for PBS and normal and malaria-infected erythrocytes were obtained with optimized values using OptiFDTD software. Shift changes in the resonant wavelength of the normalized output power transmission spectrum were observed due to changes in the refractive index between the buffer as well as healthy and infected red blood cells, the results of which can be seen in Fig.10. 


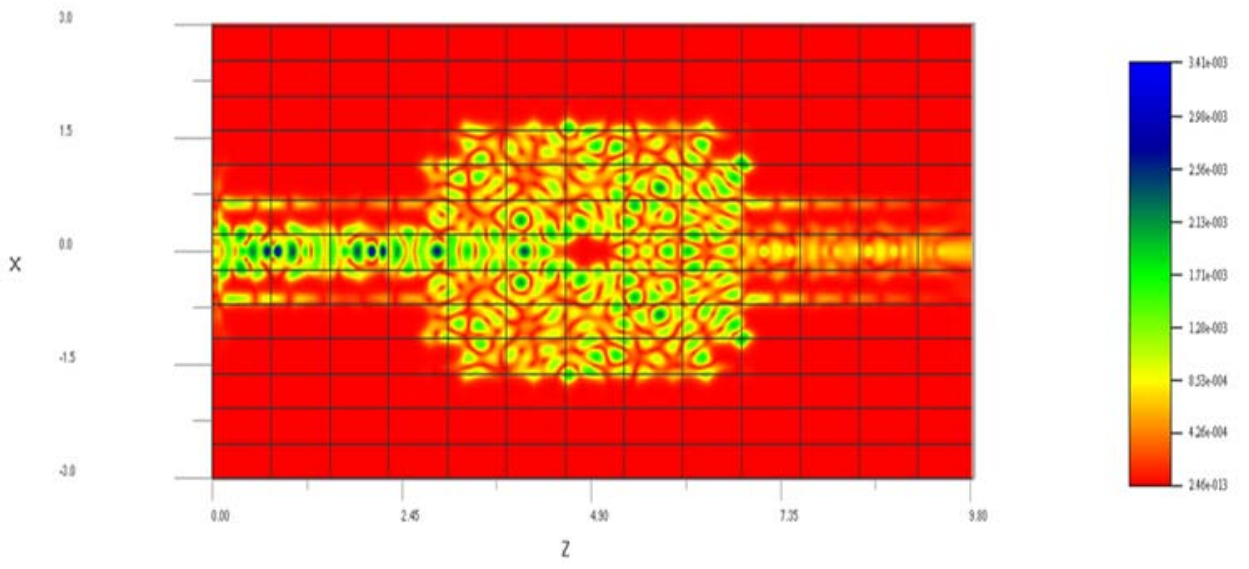

Fig. 9. Electric field distribution of elliptical ring resonator at $0.52508 \mu \mathrm{m}$.

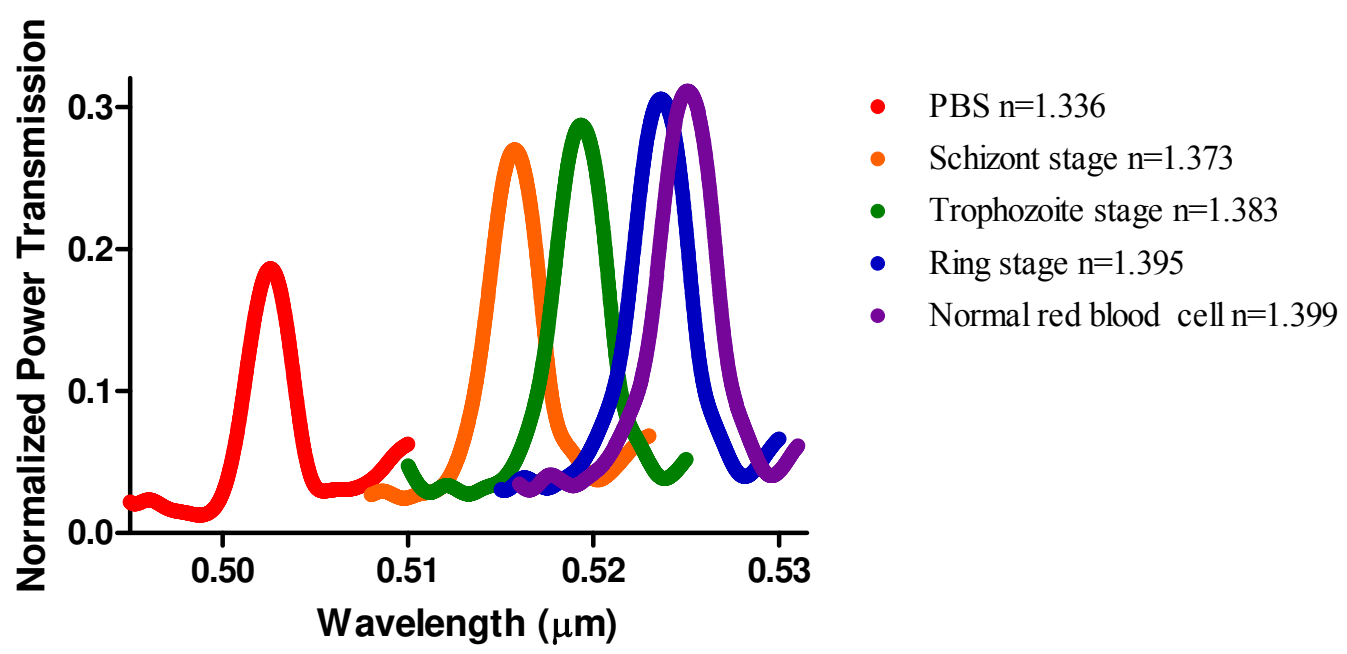

Fig. 10. Normalized output power transmission spectrum for PBS, normal red blood cell, and malariainfected red blood cells at input central wavelength of $0.514 \mu \mathrm{m}$.

Fig. 10 shows a red shift at the peak resonance wavelength from $0.502576 \mu \mathrm{m}$ for PBS buffer to $0.52508 \mu \mathrm{m}$ for normal red blood cells. The reason for the resonance wavelength shift is the change in the Propagation of light in interaction with the analytes (Jindal et al. 2016). After obtaining the transmission spectrum from the analytes, the quality factor, sensitivity and peak value of the normalized output power transmission spectrum were calculated for each of them, the results of which are given in Table 3 . 
Table 3. Peak value of normalized output power transmission spectrum, resonance wavelength, sensitivity and quality factor for PBS, normal red blood cell and malaria-infected red blood cells at input central wavelength of $0.514 \mu \mathrm{m}$.

\begin{tabular}{|c|c|c|c|c|}
\hline $\begin{array}{c}\text { Refractive } \\
\text { Index }\end{array}$ & $\begin{array}{c}\text { Resonant } \\
\text { Wavelength } \\
(\mu \mathrm{m})\end{array}$ & $\begin{array}{c}\text { Normalized } \\
\text { output power } \\
\text { Transmission }\end{array}$ & $\begin{array}{c}\text { Sensitivity } \\
(\mathrm{nm} / \mathrm{RIU})\end{array}$ & $\begin{array}{c}\text { Quality } \\
\text { factor }\end{array}$ \\
\hline $\begin{array}{c}\text { Normal red } \\
\text { blood cell } \\
1.399\end{array}$ & 0.52508 & 0.311075 & 357.2168 & 142.2426 \\
\hline $\begin{array}{c}\text { Ring stage } \\
1.395\end{array}$ & 0.523634 & 0.305411 & 356.9152 & 142.883 \\
\hline $\begin{array}{c}\text { Trophozoite } \\
\text { stage } \\
1.383\end{array}$ & 0.519328 & 0.28697 & 356.4207 & 148.0285 \\
\hline $\begin{array}{c}\text { Schizont stage } \\
1.373\end{array}$ & 0.515744 & 0.269702 & 355.8953 & 152.513 \\
\hline $\begin{array}{c}\text { PBS buffer } \\
1.336\end{array}$ & 0.502576 & 0.186021 & Ref & 170.7128 \\
\hline
\end{tabular}

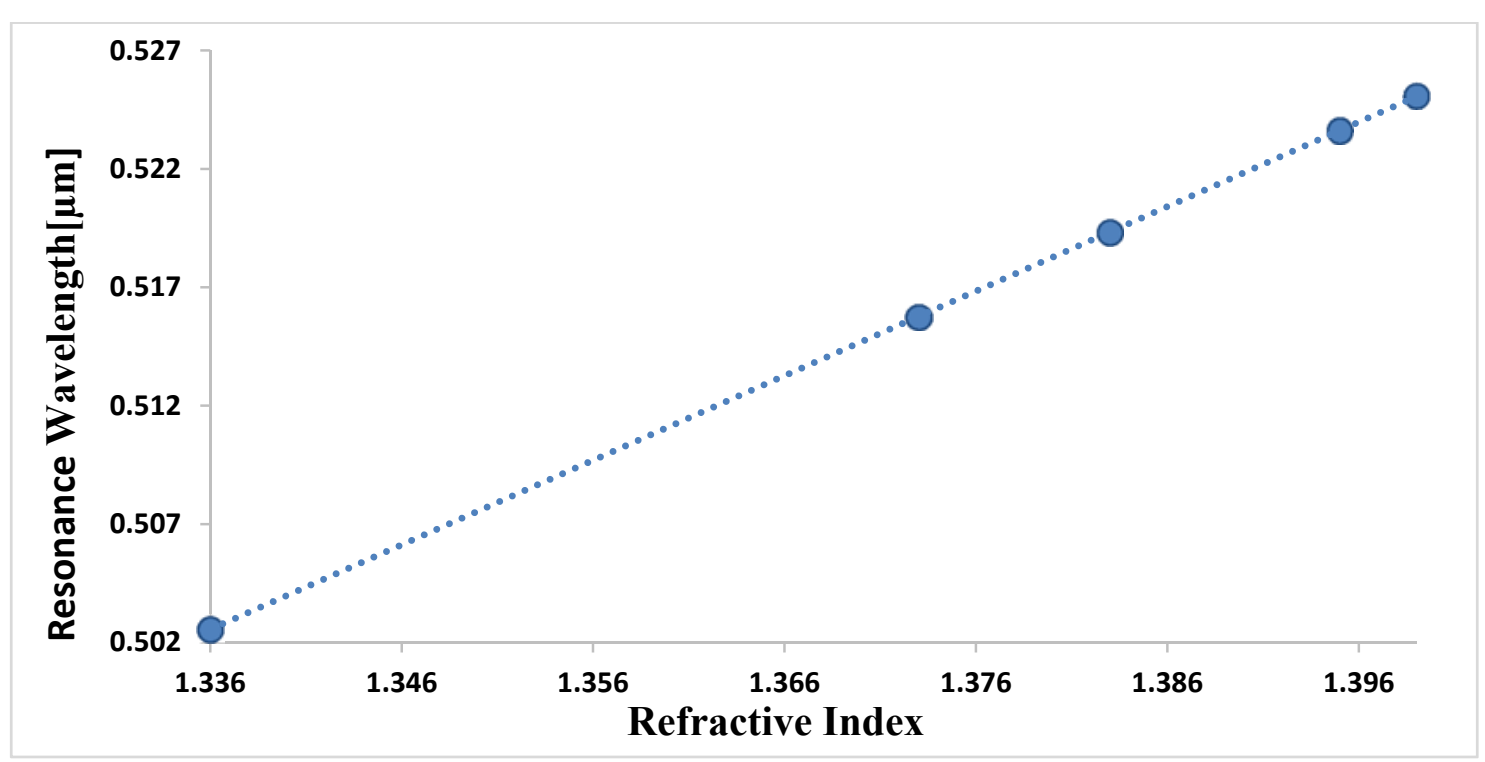

Fig. 11. Resonance wavelength as a function of refractive index changes of PBS, normal red blood cell, and malaria-infected red blood cells at input central wavelength of $0.514 \mu \mathrm{m}$.

As it can be seen in the Fig.11, there is a very good linear relationship between the resonance wavelength shift and refractive index changes with regression coefficient of 1 . Also, the sensitivity value for this biosensor is in the range of refractive index 1.336 to 1.399 equal to $357.1 \mathrm{~nm} /$ RIU. Similar biosensors operate at wavelengths such as $1.55 \mu \mathrm{m}$ and $2.09 \mu \mathrm{m}$ (Bendib and Bendib 2018; Mohammed et al. 2020; Kalyani and Sharma 2017). Our proposed biosensor has a very high sensitivity at the input central wavelength of $1.55 \mu \mathrm{m}$, which is caused 
by a slight change in the previous structure and is the same size. The manipulation of the structure is in the form of changes in the sizes of $\mathrm{R}_{\mathrm{Si3N} 4}$ and $r_{c}$, which are $0.18 \mu \mathrm{m}$ and $0.1 \mu \mathrm{m}$, respectively. The first PBG was used to design the biosensor at input central wavelength of $1.55 \mu \mathrm{m}$. For this simulation, the refractive index of silicon nitride according to the following Sellmeier equation was obtained (Luke et al. 2015):

$$
n^{2}(\lambda)=1+\frac{3.0249 \lambda^{2}}{\lambda^{2}-(0.1353406)^{2}}+\frac{40314 \lambda^{2}}{\lambda^{2}-(1239.842)^{2}}
$$

The simulation conditions are like $0.514 \mu \mathrm{m}$. The normalized output power transmission spectrum is shown in Figure 12.

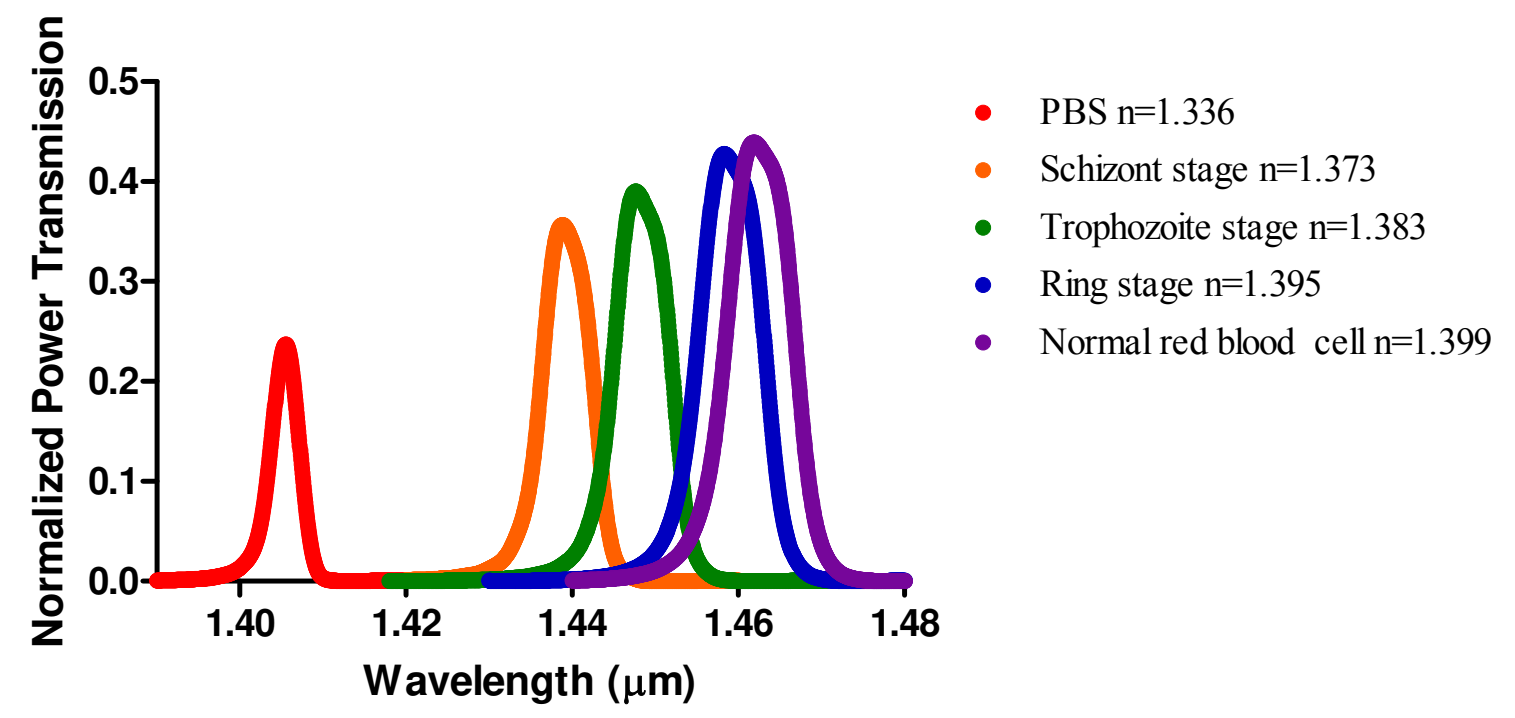

Fig. 12. Normalized output power transmission spectrum for PBS, normal red blood cell, and malaria-infected red blood cells at input central wavelength of $1.55 \mu \mathrm{m}$.

The quality factor, sensitivity and peak value of the normalized output power transmission spectrum are shown in Table 4. 
Table 4. Peak value of normalized output power transmission spectrum, resonance wavelength, sensitivity and quality factor for PBS, normal red blood cell and malaria-infected red blood cells at input central wavelength of $1.55 \mu \mathrm{m}$.

\begin{tabular}{|c|c|c|c|c|}
\hline $\begin{array}{c}\text { Refractive } \\
\text { Index }\end{array}$ & $\begin{array}{c}\text { Resonant } \\
\text { Wavelength } \\
(\mu \mathrm{m})\end{array}$ & $\begin{array}{c}\text { Normalized } \\
\text { Output Power } \\
\text { Transmission }\end{array}$ & $\begin{array}{c}\text { Sensitivity } \\
(\mathrm{nm} / \text { RIU) }\end{array}$ & $\begin{array}{c}\text { Quality } \\
\text { factor }\end{array}$ \\
\hline $\begin{array}{c}\text { Normal red } \\
\text { blood cell } \\
1.399\end{array}$ & 1.461831 & 0.439067 & 893.82 & 164.58 \\
\hline $\begin{array}{c}\text { Ring stage } \\
1.395\end{array}$ & 1.458257 & 0.427566 & 893.85 & 170.38 \\
\hline $\begin{array}{c}\text { Trophozoite } \\
\text { stage } \\
1.383\end{array}$ & 1.447623 & 0.390091 & 895.81 & 190.19 \\
\hline $\begin{array}{c}\text { Schizont stage } \\
1.373\end{array}$ & 1.438782 & 0.356499 & 898.98 & 212.77 \\
\hline $\begin{array}{c}\text { PBS buffer } \\
1.336\end{array}$ & 1.40552 & 0.236876 & Ref & 359.19 \\
\hline
\end{tabular}

As shown in Figure 13, there is a very good linear relationship with the regression coefficient of 1 . Also, sensitivity value of $893.7 \mathrm{~nm} /$ RIU was obtained.

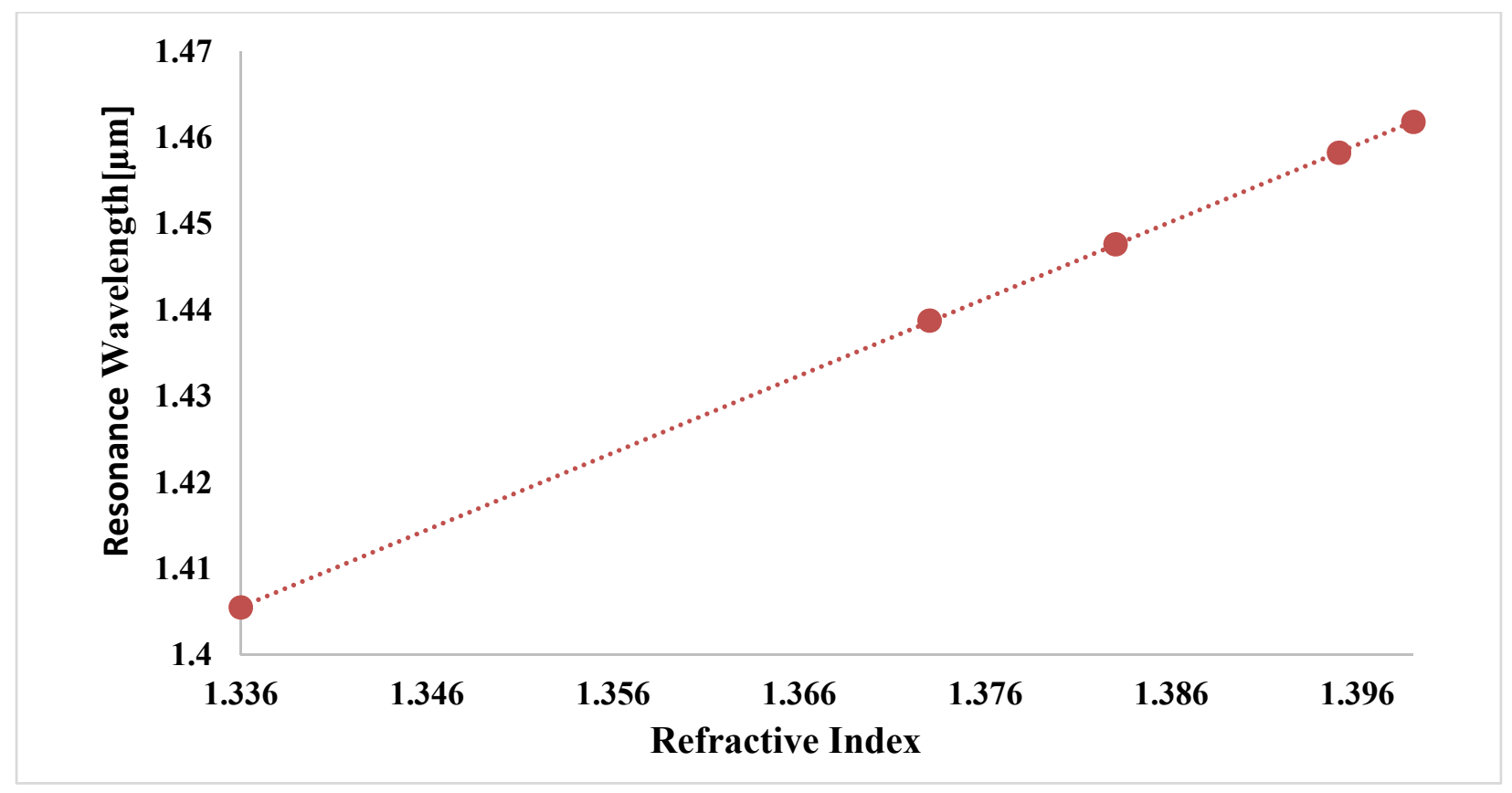

Fig. 13. Resonance wavelength as a function of refractive index changes of PBS, normal red blood cell, and malaria-infected red blood cells at input central wavelength of $1.55 \mu \mathrm{m}$. 
Table 5.Comparison of articles related to photonic crystals-based biosensors for malaria diagnosis with this biosensor proposed in this article.

\begin{tabular}{|c|c|c|c|c|c|c|c|c|}
\hline Ref & \multicolumn{2}{|c|}{ Year } & Refractive Index & $\begin{array}{r}\text { Sensitivity } \\
\text { (nm/RIU) }\end{array}$ & Quality Factor & Techniques & $\begin{array}{c}\text { Input central } \\
\text { wavelength } \\
(\mu \mathrm{m}) \\
\end{array}$ & Size $\left(\mu \mathrm{m}^{2}\right)$ \\
\hline \multirow{4}{*}{$\begin{array}{c}\text { Kalyani and } \\
\text { Sharma } 2017\end{array}$} & \multirow{4}{*}{\multicolumn{2}{|c|}{2017}} & $\begin{array}{c}\text { Normal red blood cel } \\
1.402\end{array}$ & $* *$ & $* *$ & \multirow{4}{*}{$\begin{array}{c}\text { Nanocavity } \\
\text { Photonic } \\
\text { Crystal }\end{array}$} & \multirow{4}{*}{1.55} & \multirow{4}{*}{$21 \times 19$} \\
\hline & & & $\begin{array}{c}\text { Ring stage } \\
1.395 \\
\end{array}$ & $* *$ & $* *$ & & & \\
\hline & & & $\begin{array}{c}\text { Trophozoite stage } \\
1.383 \\
\end{array}$ & $* *$ & $* *$ & & & \\
\hline & & & $\begin{array}{c}\text { Schizont stage } \\
1.373 \\
\end{array}$ & $* *$ & $* *$ & & & \\
\hline \multirow{4}{*}{$\begin{array}{l}\text { Bendib and } \\
\text { Bendib } 2018\end{array}$} & \multirow{4}{*}{\multicolumn{2}{|c|}{2018}} & $\begin{array}{c}\text { Normal red blood cel } \\
1.402 \\
\end{array}$ & $* *$ & $* *$ & \multirow{4}{*}{$\begin{array}{c}\text { photonic } \\
\text { crystal } \\
\text { biosensor } \\
\text { based on } \\
\text { ring } \\
\text { resonator } \\
\end{array}$} & \multirow{4}{*}{2.09} & \multirow{4}{*}{$11 \times 11$} \\
\hline & & & $\begin{array}{c}\text { Ring stage } \\
1.395 \\
\end{array}$ & $* *$ & $* *$ & & & \\
\hline & & & $\begin{array}{c}\text { Trophozoite stage } \\
1.383 \\
\end{array}$ & $* *$ & $* *$ & & & \\
\hline & & & $\begin{array}{c}\text { Schizont stage } \\
1.373\end{array}$ & $* *$ & $* *$ & & & \\
\hline \multirow{8}{*}{$\begin{array}{l}\text { Mohammed } \\
\text { et al. } 2020\end{array}$} & \multirow{8}{*}{2020} & \multirow{4}{*}{$\begin{array}{c}\text { first } \\
\text { design }\end{array}$} & $\begin{array}{c}\text { Normal red blood } \\
\text { cell } \\
1.402 \\
\end{array}$ & 731.20 & 1535.27 & \multirow{4}{*}{$\begin{array}{c}\text { Cavity } \\
\text { Photonic } \\
\text { Crystal }\end{array}$} & \multirow{4}{*}{1.55} & \multirow{4}{*}{$11.4 \times 9.2$} \\
\hline & & & $\begin{array}{c}\text { Ring stage } \\
1.395 \\
\end{array}$ & 741.30 & 1755.69 & & & \\
\hline & & & $\begin{array}{c}\text { Trophozoite stage } \\
1.383 \\
\end{array}$ & 759.65 & 2430.21 & & & \\
\hline & & & $\begin{array}{c}\text { Schizont stage } \\
1.373 \\
\end{array}$ & 777.61 & 2576.14 & & & \\
\hline & & \multirow{4}{*}{$\begin{array}{l}\text { second } \\
\text { design }\end{array}$} & $\begin{array}{c}\text { Normal red blood } \\
\text { cell } \\
1.402 \\
\end{array}$ & 401.44 & 7187.27 & \multirow{4}{*}{$\begin{array}{c}\text { Nanocavity } \\
\text { Photonic } \\
\text { Crystal }\end{array}$} & \multirow{4}{*}{1.55} & \multirow{4}{*}{$9.4 \times 5.5$} \\
\hline & & & $\begin{array}{c}\text { Ring stage } \\
1.395 \\
\end{array}$ & 406.13 & $\mathbf{5 9 7 8 . 3 6}$ & & & \\
\hline & & & $\begin{array}{c}\text { Trophozoite stage } \\
\mathbf{1 . 3 8 3} \\
\end{array}$ & 416.27 & 5390.00 & & & \\
\hline & & & $\begin{array}{c}\text { Schizont stage } \\
1.373 \\
\end{array}$ & 427.18 & 5974.80 & & & \\
\hline \multirow{8}{*}{\multicolumn{2}{|c|}{$\begin{array}{l}\text { Our Proposed } \\
\text { Biosensor }\end{array}$}} & \multirow{4}{*}{$\begin{array}{c}\text { first } \\
\text { design }\end{array}$} & $\begin{array}{c}\text { Normal red blood } \\
\text { cell } \\
1.399 \\
\end{array}$ & 357.2168 & 142.2426 & \multirow{4}{*}{$\begin{array}{c}\text { 2D Photonic } \\
\text { crystal } \\
\text { biosensor } \\
\text { with a ring } \\
\text { resonator }\end{array}$} & \multirow{4}{*}{0.514} & \multirow{4}{*}{$9.82 \times 6.00$} \\
\hline & & & $\begin{array}{c}\text { Ring stage } \\
1.395\end{array}$ & 356.9152 & 142.883 & & & \\
\hline & & & $\begin{array}{c}\text { Trophozoite stage } \\
1.383\end{array}$ & 356.4207 & 148.0285 & & & \\
\hline & & & $\begin{array}{c}\text { Schizont stage } \\
1.373\end{array}$ & 355.8953 & 152.513 & & & \\
\hline & & \multirow{4}{*}{$\begin{array}{l}\text { second } \\
\text { design }\end{array}$} & $\begin{array}{c}\text { Normal red blood } \\
\text { cell } \\
1.399 \\
\end{array}$ & $\mathbf{8 9 3 . 8 2 2 5}$ & 164.5777 & \multirow{4}{*}{$\begin{array}{l}\text { 2D Photonic } \\
\text { crystal } \\
\text { biosensor } \\
\text { with a ring } \\
\text { resonator }\end{array}$} & \multirow{4}{*}{1.55} & \multirow{4}{*}{$9.82 \times 6.00$} \\
\hline & & & $\begin{array}{c}\text { Ring stage } \\
1.395\end{array}$ & 893.8544 & 170.3833 & & & \\
\hline & & & $\begin{array}{c}\text { Trophozoite stage } \\
1.383\end{array}$ & 895.8088 & 190.1891 & & & \\
\hline & & & $\begin{array}{c}\text { Schizont stage } \\
1.373\end{array}$ & 898.9764 & 212.771 & & & \\
\hline
\end{tabular}


Comparing Tables 3 and 4, it can be seen that the sensitivity, quality factor and normalized output power are higher at the input central wavelength of $1.55 \mu \mathrm{m}$. Also, as shown in Table 5, the proposed biosensor at the input central wavelength of $1.55 \mu \mathrm{m}$ with a very compact size has a higher sensitivity than the results reported in the articles shown. However, given the benefits of working at the visible wavelength described at the beginning of this article, and also because of our proposed biosensor, which operates in the wavelength range from $0.514 \mu \mathrm{m}$, detects normal and infected red blood cells with high sensitivity in laboratory conditions where their refractive index has been measured. In other words, our proposed biosensor operates in the wavelength range from $0.514 \mu \mathrm{m}$, the wavelength at which refractive indices are measured.

\section{Conclusion}

In this paper, a 2D PhC-based biosensor with a ring resonator has been designed to detect the Plasmodium falciparum cycle in red blood cells at input central wavelengths of $0.514 \mu \mathrm{m}$ and $1.55 \mu \mathrm{m}$. This biosensor is compact with dimensions of $9.82 \times 6.00 \mu \mathrm{m}^{2}$ and exhibits high sensitivity working based on the change of the peak resonance wavelength shift due to the change of the refractive index, which is a very linear change. The results show that the sensor has a very good linear response with a regression coefficient of 1 . According to the simulation results, the sensitivity of this biosensor for the refractive index range from 1.336 to 1.399 at the central input wavelengths of $0.514 \mu \mathrm{m}$ and $1.55 \mu \mathrm{m}$ is equal to 357.1 RIU / nm and $893.7 \mathrm{~nm} / \mathrm{RIU}$, respectively. The design priority of the biosensor at the input central wavelength is $0.514 \mu \mathrm{m}$ because at wavelengths of less than one micrometer, water absorption is negligible and causes less damage to biological cells. Also, abundant access to high-performance detectors, low-cost light sources and high performance are other advantages. Finally, to the best of our knowledge it is for the first time that such a versatile biosensor is designed in the visible wavelength range where the measured refractive indices are available. 


\section{Compliance with ethical standard}

Conflicts of interest The authors declare that they have no conflicts of interest.

\section{References}

Akpa Marcel, A., Konan, K., Tokou, Z., Kossonou, Y., Dion, S., Kaduki, K., Zoueu, J.: Malaria-Infected Red Blood Cell Analysis through Optical and Biochemical Parameters Using the Transport of Intensity Equation and the Microscope's Optical Properties. Sensors. 19, 3045 (2019). 10.3390/s19143045.

Bååk, T.: Silicon oxynitride; a material for GRIN optics. Appl Opt. 21(6), 1069-72 (1982).10.1364/AO.21.001069.

Barroso, Á., Radhakrishnan, R., Ketelhut, S., Schnekenburger, J., Kemper, B.: Refractive index determination of buffer solutions from visible to near-infrared spectral range for multispectral quantitative phase imaging using a calibrated Abbe refractometer. 10887, 1088729 (2019). 10.1117/12.2509221.

Bendib, S., Bendib, C.: Photonic Crystals for Malaria Detection. J. Biosensors \& Bioelectronics. 09(3), (2018). 10.4172/2155-6210.1000257.

Bilal, M ., Saleem, M., Amanat, S ., Shakoor, H ., Rashid, R ., Mahmood, A ., Ahmed, M.: Optical diagnosis of malaria infection in human plasma using Raman spectroscopy. J.biomedical optics. 20(1), 17002(2015). 10.1117/1.JBO.20.1.017002.

Chen, N., Chang, M., Zhang, X., Zhou, J., Lu, X., Zhuang, S.: Highly Sensitive Plasmonic Sensor Based on a Dual-Side Polished Photonic Crystal Fiber for Component Content Sensing Applications. Nanomaterials. 9, 1587 (2019). 10.3390/nano9111587.

Chopra, H., Kaler, R. S., Painam, B.: Photonic crystal waveguide-based biosensor for detection of diseases. J. Nanophotonics. 10, 036011 (2016). 10.1117/1.JNP.10.036011.

Degirmenci, E., Landais, P.: Finite element method analysis of band gap and transmission of two-dimensional metallic photonic crystals at terahertz frequencies. Applied optics. 52, 736775 (2013). 10.1364/AO.52.007367.

Dell'Olio, F., Passaro, V.: Optical sensing by optimized silicon slot waveguides. Optics express. 15, 4977-93 (2007). 10.1364/OE.15.004977.

Dharmadhikari, A., Basu, H., Dharmadhikari, J., Sharma, S., Mathur, D.: On the birefringence of healthy and malaria-infected red blood cells. J. biomedical optics. 18, 125001 (2013). 10.1117/1.JBO.18.12.125001. 
Divya, J., Selvendran, S., Avaninathan, S.: Photonic crystal-based optical biosensor: A brief investigation. Laser Physics. 28, 066206 (2018). 10.1088/1555-6611/aab7d2.

Hameed, M.F.O., Heikal, A., Younis, B., Abdelrazzak, M., Obayya, S.: Ultra-high tunable liquid crystal-plasmonic photonic crystal fiber polarization filter. Optics Express. 23, 70077020 (2015). 10.1364/OE.23.007007.

Hassani, A., Skorobogatiy, M.: Photonic crystal fiber-based plasmonic sensors for the detection of biolayer thickness. JOSA B. 26, 1550-1557 (2009).10.1364/JOSAB.26.001550.

Hsiao, F.L., Lee, C:. Computational Study of Photonic Crystals Nano-Ring Resonator for Biochemical Sensing. IEEE Sensors Journal. 10, 1185-1191(2010). doi: 10.1109/JSEN.2010.2040172.

Jindal, S., Sobti, S., Kumar, M., Sharma, S., Pal, M.: Nanocavity-Coupled Photonic Crystal Waveguide as Highly Sensitive Platform for Cancer Detection. IEEE Sensors Journal. 16, 3705 - 3710 (2016). 10.1109/JSEN.2016.2536105.

Kalyani, V., Sharma, V.: Design Two Dimensional Nanocavity Photonic Crystal Biosensor Detection in Malaria. International Journal of Emerging Research in Management \&Technology. 6, 16-20 (2017). 10.23956/ijermt.v6i6.239.

Krampa, F., Aniweh, Y., Kanyong, P., Awandare, G.: Recent Advances in the Development of Biosensors for Malaria Diagnosis. Sensors. 20, 799 (2020). 10.3390/s20030799.

Krishnan, S., Robinson, S.: Two-dimensional photonic crystal based sensor for pressure sensing. Photonic Sensors. 4, 248-253 (2014). 10.1007/s13320-014-0198-8.

Liu, P.Y., Chin, L. K., Ser, W., Chen, H., Hsieh, C-M., Lee, C-H ., Sung, K-B., Ayi, T., Yap, P., Liedberg, B., Wang, K., Bourouina, T., Leprince-Wang, Y.: Cell Refractive Index for Cell Biology and Disease Diagnosis: Past, Present and Future. Lab on a chip. 16(4), 634-644 (2016). 10.1039/c5lc01445j.

Luke, K., Okawachi, Y., Lamont, M., Gaeta, A., Lipson, M.: Broadband Mid-Infrared Frequency Comb Generation in a $\mathrm{Si}_{3} \mathrm{~N}_{4}$ Microresonator. CLEO: Science and Innovations, CLEO-SI 2015. STu4I. 8 (2015). 10.1364/CLEO_SI.2015.STu4I.8.

Mai, T., Hsiao, F.L., Lee, C., Xiang, W., Chen, C.L., Choi, W. K.: Optimization and comparison of photonic crystal resonators for silicon microcantilever sensors. Sensors and Actuators A: Physical. 165, 16-25 (2011). 10.1016/j.sna.2010.01.006.

Mohammed, N., M. Hamed, M., Khalaf, A.A. M., Alsayyari, A., El-Rabaie, E.S.: Highsensitivity ultra-quality factor and remarkable compact blood components biomedical sensor based on nanocavity coupled photonic crystal. Results in Physics. 14, 102478 (2019). 10.1016/j.rinp.2019.102478. 
Mohammed, N., M. Hamed, M., Khalaf, A.A. M., El-Rabaie, E.S.: Malaria biosensors with ultra-sensitivity and quality factor based on cavity photonic crystal designs. European Physical Journal Plus. 135, 1-22 (2020). 10.1140/epjp/s13360-020-00940-5.

Molina-Franky, J., Cuy-Chaparro, L., Camargo, A., Reyes, C., Gómez, M., Salamanca, D., Patarroyo, M., Patarroyo, M.: Plasmodium falciparum pre-erythrocytic stage vaccine development. Malaria J. 19(1), (2020). 10.1186/s12936-020-3141-z.

Nureye, D., Assefa, S.: Old and Recent Advances in Life Cycle, Pathogenesis, Diagnosis, Prevention, and Treatment of Malaria Including Perspectives in Ethiopia. The Scientific World Journal. 2020, 1-17(2020). 10.1155/2020/1295381.

Park, Y.K., Diez-Silva, M., Popescu, G., Lykotrafitis, G., Choi, W., Feld, M., Suresh, S.: Refractive index maps and membrane dynamics of human red blood cells parasitized by Plasmodium falciparum. Proceedings of the National Academy of Sciences of the United States of America. 105, 13730-5 (2008). 10.1073/pnas.0806100105.

Porcel, M.A.G., Hinojosa, A., Jans, H., Stassen, A., Goyvaerts, J., Geuzebroek, D., Geiselmann, M., Dominguez, C., Artundo, I.: Silicon nitride photonic integration for visible light applications. 112, 299 - 306 (2019). 10.1016/j.optlastec.2018.10.059.

Ragavan, K.V., Kumar, S., Swaraj, S., Neethirajan,S.: Advances in biosensors and optical assays for diagnosis and detection of malaria. Biosens Bioelectron.105, 188-210 (2018). doi:10.1016/j.bios.2018.01.037.

Rajasekar, R., Robinson, S.: Nano-Pressure and Temperature Sensor Based on Hexagonal Photonic Crystal Ring Resonator. Plasmonics. 14, 3-15 (2018). 10.1007/s11468-018-0771-X.

Rajendran, A., Suaganya, T., Robinson, S.: Design and Analysis of 2D Photonic Crystal Based Biosensor to Detect Different Blood Components. Photonic Sensors. 9, 69-77 (2018). 10.1007/s13320-018-0479-8.

Robinson, S., Dhanlaksmi, N.: Photonic crystal based biosensor for the detection of glucose concentration in urine. Photonic Sensors. 7, (2016).10.1007/s13320-016-0347-3.

Sharma, P., Sharan, P.: Design of photonic crystal based ring resonator for detection of different blood constituents. Optics Communications. 348, 19-23 (2015). 10.1016/j.optcom.2015.03.015.

Subramanian, A., Ryckeboer, E., Dhakal, A., Peyskens, F., Malik, A., Kuyken, B., Zhao, H., Pathak, S., Ruocco, A., De Groote, A., Wuytens, P., Martens, D., Leo, F., Xie, W., Dave, U., Muneeb, M., Van Dorpe, P., Van Campenhout, J., Bogaerts, W., Baets, R.: Silicon and silicon nitride photonic circuits for spectroscopic sensing on-a-chip [Invited]. Photonics Research. 3, B47 (2015). 10.1364/PRJ.3.000B47.

Zegadi, R., Lahcene, Z., Zegadi, A.: Design of High Sensitive Temperature Sensor Based on Two-Dimensional Photonic Crystal. Silicon. 12, 1-7 (2019). 10.1007/s12633-019-00303-5. 
Zhang, Y.n., Zhao, Y., Tianmin, Z., Wu, Q.1.: Applications and developments of on-chip biochemical sensors based on optofluidic photonic crystal cavities. Lab on a Chip. 18, 57-74 (2017). 10.1039/C7LC00641A. 